which drained the camp empty into that stream. The men were told not to drink that water, but when a lot of men are tired, hot and thirsty, injunctions of that kind are not heeded, and many of them drank frequently of the water. Not more than two miles farther on, a clear. pure, limpid stream issued from the rock at Crawfish Springs, in volume sufficient to have furnished the camp with water for all purposes. Why was this water-supply not secured instead of the Chickamauga River? The result is that typhoid fever is epidemic at Camp George $\mathrm{H}$. Thomas, and the troops remaining there will, in all probability, have to be removed to other locations.

Trusting you will give this letter publication, in the hope that it may help to correct the glaring defects which exist in the army today, I am, sir, Very truly yours,

Wim. Cuthbertson,

Late Major and Surgeon First Illinois Vol. Cavalry.

\section{Condition of Santiago.}

Santiago, Cuba, July 15, 1898.

To the Editor: I have just been through the city of Santiago de Cuba. The terms of capitulation will be published before this reaches you. I found the city full of stench and disease; no sanitation. Dead horses, dogs, cats and other animals that starvation had deprived of life are lying bloated and decomposing in the rough, dirty, narrow streets. Thermal fever, dysentery, acute diarrhea and yellow fever are dissemi nated through the city. The city water supply comes through an eight-inch main which is inadequate for a city of 60,000 . The sewerage is almost $n i l$. The refuse from the kitchen, such as starvation will give, is strewn into the streets to decompose in the hot sun and daily showers. The streets are full of deep holes, four or five feet wide by one to three feet deep, which speedily become receptacles for the decomposing animal mat ter and are so many cesspools of nauseating odor. Genera Shafter has wisely refused to let any of our troops pass into the city. More of Santiago in my next.

There are 26 cases and 3 deathe from yellow fever in the camp near Santiago, 146 cases at Sibone (pronounced Siboney). The number of deaths has not been received today. Of 140 cases of malarial, bilious and thermal fevers in four hospitals, 65 have been discharged for duty. Thirty-two wounded are still in the division hospital. The yellow fever hospital is three-fourths of a mile from the main camp on a hill. The fever hospital and division hospital for wounded are one-quarter of a mile apart.

Sanitation is improving and all doing well. Dr. Pope has worked heroically and deserves the thanks of the American people for his untiring efforts, although often unsuccessful.

Drs. Combs and Jones are in charge of the yellow fever hospital near Santiago; Dr. Wood in charge of the division hospital, and Dr. La Garde of the general hospital at Sibone.

Recapitulation: 1342 wounded in all of the battles since landing in Cuba; 100 deaths so far from wounds, killed and missing; 168 yellow fever cases and 28 deaths from the same cause.

Orlando Ducker, M.D., U. S. V.

\section{Malingering.}

Unionille, N. Y., Aug. 10, 1898.

To the Editor:-I read the Jounval with great interest and profit every week. Your editorial on 'Malingering"' (p. 247, July 30) has just been read with keen interest and suggests that I give you an outline of a case in point.

Mrs. E. V. C., married, one child, aged 35 years, is of an extremely nervous temperament, light weight mentally, but with a glib tongue that elicits the sympathy of similarly constituted persons. Both parents are weak mentally, although father has brilliant spells, but lacks balance and judgment. In January and February, 1894, Mrs. C. had attacks of hys- teria and believed she had a cancer of her uterus, which I told her she did not have, but she did not believe it. Every day or two she would have attacks of pelvic pains, a little diarrhea and a slight uterine discharge. During these months she had frequent hysteric convulsions with which she impressed her sympathizers that she had almost died, and it seemed to give her encouragement to have another if she could make her attendants believe she was nearly dead during her spell. She had some time before had an operation for lacerated cervix. Nothing would satisfy her but that nearly every day I must make some kind of an application to the uterus for treatment, and insert a tampon. This I did more to satisfy her than for any good it did. I urged cotton tampons soaked in glycerin and tannic acid and occasionally sprinkled a little powdered opium where it would come in contact with a slightly abraded cervix. I occasionally applied to the inside of cervix tincture of iodin, weak solution carbolic acid, etc. Two or three times I made an application of a weak solution of nitrate of silver ( $3 \mathrm{gr}$. to $3 \mathrm{i}$ ) in the usual way with the applicator wound with cotton. Using silver nitrate was done more for its mental effect than for any good I hoped to accomplish, for I knew she would try to find out all about nitrate of silver, and finding it to be a strong drug it would satisfy her intense desire that I should use powerful remedies to "kill her cancer." I reckoned wrongly for she soon fell into the hands of a clairvoyant and he told her that she had no cancer, which she promptly believed, but told her that her doctor had "burned her insides all out with nitrate of silver." He easily convinced her that she had no cancer, which I was unable to do, and as easily convinced her that I had ruined her health under the use of nitrate of silver. She soon wanted me to pay her damages for "ruining her health and burning her insides all out."

Physically she is a strong, robustand healthy woman, and is on the go all the time and has been since I quit attending her, Feb. 27, 1894. But most of the time she has been malingering and now and then would work herself up to that pitch where she would either write me a letter or get a lawyer to, demand. ing damages. These $I$ never paid any attention to except to send them back to her. She has now within the last few days gotten a reputable firm of lawyers to sue me for malpractice. I am interested to know what kind of a case thyy can work up. It is my candid opinion that she has, with the sympathy of her few mental equals, worked herself up to a belief that $I$ will pay her several hundred dollars rather than have the matter come in the courts.

Are not physicians constantly in danger of expense and trouble from these people, if they treat them, and of annoyance and criticisms if they do not? Truly,

F. W. Dennis, M.D.

\section{Objects to New Designation.}

Shelbyrille, Ind., Aug 15, 1898.

To the Editor:- I object to the proposed new designation for our profession, suggested by Dr. Fenn in the Journal of A ugust 13. Dr. Sternberg, in his address at Denver, did not recommend the adoption of the title "New School of Scientific Medicine," but merely said, "If we are to be characterized by any distinctive name, this would be the only one applicable."

From the days of Hippocrates to the present, we have always been the scientific school of medicine according to the best light we had. The celebrated John Hunter one day said to a member of his class whom he noticed taking notes during one of his masterly lectures on inflammation, "Don't take any notes of what I say today on this subject; I may not think next year as I think today." He was always a member of the "new school of scientific medicine," and kept abreast of the times.

We should always object to the titles "old school" or "allopath," names given to us by the eclectics and homeo- 